\title{
Roggianite: revised chemical formula and zeolitic properties
}

\author{
E. PASSAgLIA \\ Istituto di Mineralogia, Universita' di Ferrara, Corso Ercole I d'Este 32, 44100 Ferrara, Italy \\ AND \\ Giovanna Vezzalini \\ Istituto di Mineralogia e Petrologia, Universita' di Modena, via S. Eufemia 19, 41100 Modena, Italy
}

\begin{abstract}
The holotype roggianite from Alpe Rosso (Novara, Italy) has been chemically re-analysed using modern analytical procedures (microprobe, atomic absorption spectrophotometer, TG analyses) and tested for its zeolitic behaviour. When compared with that given in the original description, the new chemical composition shows an appreciable amount of $\mathrm{Be}$ and a different $\mathrm{Si} / \mathrm{Al}$ ratio. On the basis of its structural data, the chemical formula here proposed for roggianite is:
\end{abstract}

$$
\left(\mathrm{Ca}_{14.24} \mathrm{Sr}_{0.01} \mathrm{Na}_{0.37} \mathrm{~K}_{0.56}\right)_{\Sigma 15.18}\left[\left(\mathrm{Be}_{5.29} \mathrm{Al}_{14.92} \mathrm{Si}_{27.79}\right)_{\Sigma 48} \mathrm{O}_{89.96}(\mathrm{OH})_{14}\right](\mathrm{OH})_{2} \cdot 33.68 \mathrm{H}_{2} \mathrm{O}
$$

An accurate powder pattern, index taking into account the structural factors, is also given. Since the mineral showed an almost complete rehydration after heating to $750^{\circ} \mathrm{C}$ and an appreciable ion exchange capacity, it must be considered as belonging to the zeolitic group of minerals, and, in this frame, it represents the first and up to now the only zeolite with $\mathrm{Be}$ as fundamental constituent and, like partheite, with $\mathrm{OH}$ groups in the framework.

KEYWORDS: roggianite, zeolitic properties, Alpe Rosso, Italy

\section{Introduction}

RogGiANITE is a natural hydrated calcium alumino silicate to date described from only two localities, both in Val Vigezzo (Novara, Italy)-the first (Passaglia, 1969) at Alpe Rosso, the second (Vezzalini and Mattioli, 1979) at Pizzo Marcio. The chemical composition of the holotype material (Passaglia, 1969) was obtained on material containing small quantities of an unknown organic contaminant using analytical procedures available at that time-gravimetric, emission spectrophotometric, volumetric complessometric and colorimetric methods. The chemical composition of a sample from Pizzo Marcio (Vezzalini and Mattioli, 1979) was obtained with an electron microprobe, the water content being given as a difference to $100 \%$. The two analyses, so obtained, show the same most abundant cations ( $\left.\mathrm{Si}, \mathrm{Al}, \mathrm{Ca}, \mathrm{H}_{2} \mathrm{O}\right)$, but in significantly different ratios.

Galli (1980), using a single crystal of the sample from Pizzo Marcio (the holotype sample from
Alpe Rosso occurs only as fibrous aggregates) solved the structure that resulted in an interrupted (Si, Al) framework with some $\mathrm{OH}$ vertices unshared by two tetrahedra; Ca cations and water molecules lie in cavities where the framework is interrupted and in the largest channels, respectively. Such a structure led Galli to classify roggianite as a zeolite-like silicate and it was considered in the same way by Gottardi and Galli (1985), although properties peculiar to zeolites (rehydration, cation exchange capacity) have not yet been proved for it.

Recently, the Commission on New Minerals and Mineral Names of IMA, urged us to test the holotype roggianite for $\mathrm{Be}$ content, not determined in the original description. Since this resulted in a determination of $3.19 \% \mathrm{BeO}$, the mineral was completely re-examined in order to determine its complete and accurate chemical and crystallographic features by using modern analytical procedures (electron microprobe, atomic absorption spectrometer, TG analyser, X-ray diffractometer) and to test its zeolitic behaviour. 


\section{X-ray powder diffraction}

The X-ray powder data of roggianite given in the original description were obtained by using a Debye-Scherrer camera $(114.9 \mathrm{~mm}$ in diameter). In this work, a more accurate and complete X-ray powder pattern was measured on a Philips diffractometer with Ni-filtered $\mathrm{Cu}-K \alpha$ radiation $(\lambda=1.54051 \AA)$ and $\mathrm{Pb}\left(\mathrm{NO}_{3}\right)_{2}$ as an internal standard. As some peaks of the internal standard overlap some peaks of roggianite, a powder pattern without the internal standard was also obtained. The data reported in Table 1 are therefore the combination of the two powder patterns. The reflections are indexed according to the structure factors given by Galli (1980). Compared with the pattern given in the original description, this one shows several weak reflections not previously observed and the splitting of some lines with medium intensity.

Cell dimensions from the powder pattern were determined by a least-squares refinement program using an indexing method (Alberti, 1976) which takes into account the structure factors. The reflections too far from, or overlapping with the standard lines were discarded; therefore only the spacings marked with a star in Table 1 were used in this calculation.

The unit cell dimensions so calculated are: $a$ $18.370(4)$; $c 9.187(4) \AA$. These values differ from those reported both in the original description (Passaglia, 1969) and by Gard (1969) within the experimental errors, but they are decidedly more accurate. The values given by Galli (1980) for roggianite from Pizzo Marcio are very similar to those here measured.

X-ray powder patterns were also recorded by a Gandolfi camera on roggianite previously heated to various temperatures. Heating up to $850^{\circ} \mathrm{C}$, the spectrum is substantially identical to that of the unheated sample, whereas after heating to $900^{\circ} \mathrm{C}$ the powder pattern is that of a feldspar. The roggianite framework breaks down only at temperatures higher than $850^{\circ} \mathrm{C}$ and it reconstructs immediately in a feldspar framework.

\section{Chemical composition}

The chemical composition was obtained by combination of data from atomic absorption spectrometer $(\mathrm{Be})$, thermal gravimetric $\left(\mathrm{H}_{2} \mathrm{O}\right)$ and electron microprobe (all other elements) analyses.

Electron microprobe analysis was carried out in the wavelength dispersive mode on an ARLSEMQ instrument operated at $15 \mathrm{kV}$ and $15 \mathrm{nA}$ beam current and with a defocused beam (spot size $18 \mu \mathrm{m}$ ). On-line data reduction was based on the Ziebold and Ogilvie (1964) method by use of the Albee and Ray (1970) correction factors. Natural albite, microcline and synthetic plagioclase glasses were used as standards for $\mathrm{Si}, \mathrm{Al}$, $\mathrm{Na}, \mathrm{K}$ and $\mathrm{Ca}$, synthetic anorthite for $\mathrm{Sr}$. Fe, Ba and $\mathrm{Mg}$ were tested for but found to be absent. The chemical composition was obtained by averaging five point-analyses on pure fibrous aggregates (Table 2, col. 1a). The microprobe data were normalized to $100 \%$ taking into account the water content derived by TG analysis and $\mathrm{BeO}$ content resulting from atomic absorption spectrophotometry. The normalization was made to correct for the undetermined loss of zeolitic water under electron bombardment in the vacuum chamber of the microprobe (Table 2, col. $1 b$ ).

The TG analysis was made on $2.32 \mathrm{mg}$ of powdered pure material using a Du Pont thermal analyser operated in air with a heating rate of $10^{\circ} \mathrm{C} / \mathrm{min}$. TG and DTG curves (Fig. 1) indicate a faster weight loss $\left(7 \%\right.$ ) between $30^{\circ} \mathrm{C}$ and $200^{\circ} \mathrm{C}$ followed by a slow and continuous one $(7.5 \%)$ up to $850^{\circ} \mathrm{C}$; between this temperature and $950^{\circ} \mathrm{C}$ a faster reaction $(3.6 \%$ weight loss) occurs. From $950^{\circ} \mathrm{C}$ to the final temperature of the experiment $\left(1050^{\circ} \mathrm{C}\right)$ no appreciable weight loss is observed. These curves are very similar to the DT curve of the original description (Passaglia, 1969) where two sharp endothermic peaks at $113^{\circ} \mathrm{C}$ and $874^{\circ} \mathrm{C}$ are present.

In Table 2 the new chemical analysis is compared with that reported in the original description and that given for roggianite from Pizzo Marcio (Vezzalini and Mattioli, 1979). The new data are quite different from those of the original description, but are very similar to those obtained for the sample from Pizzo Marcio. In this last case, the differences decrease if we consider, also in the sample from Pizzo Marcio, a Be content similar to that found here for the sample from Alpe Rosso. A test for this purpose was impossible due to the scarcity of the available material, but the closeness of Alpe Rosso and Pizzo Marcio (about $1 \mathrm{~km}$ apart) and the presence of crysoberyl in the paragenesis at Pizzo Marcio favours this hypothesis.

In the calculation of the chemical formula, the results of both structural refinement (Galli, 1980) and TG tracing were taken into account.

Galli (1980) found three independent tetrahedral sites fully occupied (multiplicity $16 \times 3=48$ ) and five framework anion sites; out of these five sites, four, coded $O(1), O(2), O(3)$, and $O(4)$, have bond strengths near to 2 and hence are occupied by oxygens, and the remaining one, coded $\mathrm{OH}(1)$, has a bond strength of 1.51 and hence may be occupied by oxygen or hydroxyl; Galli's 
Table 1. X-ray powder diffraction data for Roggianite, CuK $\alpha$ radiation $(\lambda=1.54051)$, $a=b=18.370(4) \AA, c=9.187(4) \AA$.

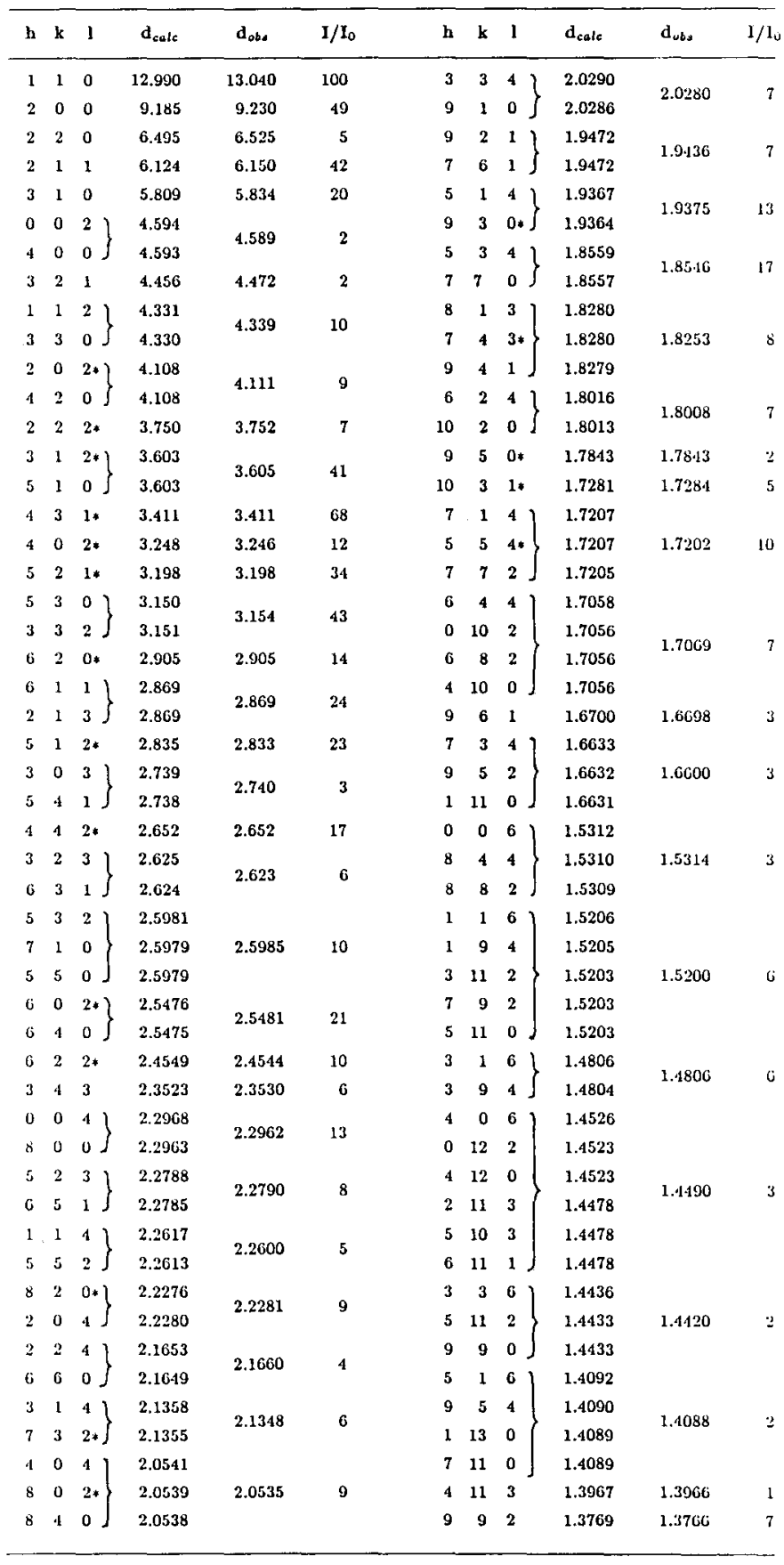

* reflections used for the cell parameters refinement 
Table 2. Chemical analyses of Roggianite.

\begin{tabular}{lcccc}
\hline & $1 \mathrm{a}$ & $1 \mathrm{~b}$ & 2 & 3 \\
\hline $\mathrm{SiO}_{2}$ & 41.05 & 40.22 & 36.58 & 44.11 \\
$\mathrm{Al}_{2} \mathrm{O}_{3}$ & 18.70 & 18.32 & 22.34 & 18.54 \\
$\mathrm{BeO}$ & n.d. & 3.19 & n.d. & n.d. \\
$\mathrm{Fe}_{2} \mathrm{O}_{3}$ & - & - & 0.42 & 0.05 \\
$\mathrm{MgO}$ & - & - & 0.87 & - \\
$\mathrm{CaO}$ & 19.64 & 19.24 & 14.73 & 19.97 \\
$\mathrm{SrO}$ & 0.02 & 0.02 & n.d. & 0.04 \\
$\mathrm{BaO}$ & - & - & n.d. & 0.09 \\
$\mathrm{Na}_{2} \mathrm{O}$ & 0.29 & 0.28 & 0.94 & 0.01 \\
$\mathrm{~K}_{2} \mathrm{O}$ & 0.64 & 0.63 & 0.76 & 0.02 \\
$\mathrm{H}_{2} \mathrm{O}$ & n.d. & 18.10 & 21.63 & 17.17 \\
& & & & \\
Total & 80.34 & 100.00 & 98.27 & 100.00 \\
\hline
\end{tabular}

1. Roggianite Alpe Rosso (this work).

a) Microprobe data.

b) Microprobe data normalized to $100 \%$ with $\mathrm{H}_{2} \mathrm{O}$ and $\mathrm{BeO}$ contents 2. Roggianite Alpe Rosso (Passaglia, 1969). The analysis includes also $0.32 \%$ of $\mathrm{SO}_{3}, 0.10 \%$ of $\mathrm{F}, 0.05 \%$ of $\mathrm{Cl}_{2} 0.19 \%$ of $\mathrm{H}$ and $1.43 \%$ of $\mathrm{C}$ considered as due to impurities.

3. Roggianite Pizzo Marcio (Vezzalini and Mattioli, 1979) $\mathrm{H}_{2} \mathrm{O}$ content as difference to $100 \%$.

extra-framework site $\mathrm{OH}(2)$, with bond strength 0.60 , could be occupied by hydroxyl or water. On the basis of available chemical data (Vezzalini and Mattioli, 1979), Galli assigned hydroxyls to both $\mathrm{OH}(1)$ and $\mathrm{OH}(2)$ sites, in the form of the following chemical formula:

$$
\mathrm{Ca}_{16}\left[\mathrm{Al}_{16} \mathrm{Si}_{32} \mathrm{O}_{88}(\mathrm{OH})_{16}\right](\mathrm{OH})_{16} \cdot \text { c. } 26 \mathrm{H}_{2} \mathrm{O} \text {. }
$$

Due to the uncertainty in the assignment of some anion sites, the chemical formula from the data of Table 2 has been calculated on the basis of 48 tetrahedral cations ( $\mathrm{Si}+\mathrm{Al}+\mathrm{Be})$, so obtaining for unit cell:

$$
\begin{aligned}
& \left(\mathrm{Ca}_{14.24} \mathrm{Sr}_{0.01} \mathrm{Na}_{0.37} \mathrm{~K}_{0.56}\right)_{\Sigma 15.18} \\
& \quad\left[\left(\mathrm{Be}_{5.29} \mathrm{Al}_{14.92} \mathrm{Si}_{27.79}\right)_{\Sigma 48} \mathrm{O}_{89.96}(\mathrm{OH})_{14}\right] \\
& (\mathrm{OH})_{2} \cdot 33.68 \mathrm{H}_{2} \mathrm{O}
\end{aligned}
$$

or schematically:

$$
\begin{aligned}
& \mathrm{Ca}_{14}(\mathrm{Na}, \mathrm{K}) \\
& {\left[\mathrm{Be}_{5} \mathrm{Al}_{15} \mathrm{Si}_{28} \mathrm{O}_{90}(\mathrm{OH})_{14}\right]} \\
& (\mathrm{OH})_{2} \cdot 34 \mathrm{H}_{2} \mathrm{O} \text {. }
\end{aligned}
$$

With respect to the original schematical formula $\mathrm{Na}_{2} \mathrm{Ca}_{12} \mathrm{Al}_{18} \mathrm{Si}_{26} \mathrm{O}_{92} \cdot 40 \mathrm{H}_{2} \mathrm{O}$ (Passaglia, 1969), the above formula shows lower $\mathrm{Na}$ and higher $\mathrm{Ca}$ contents, while, among the framework cations, the relevant presence of $\mathrm{Be}$ is accompanied by lower $\mathrm{Al}$ and higher Si contents. Besides the different analytical procedures, these differences may also be ascribed to the impurity of the material analysed in the original description, as suggested by the relevant $\mathrm{Na}$ content, very likely due to the contaminant presence of sodium feldspar on which the fibrous aggregates of roggianite rest. When compared with the structural formula (Galli, 1980) of the sample from Pizzo Marcio (Vezzalini and Mattioli, 1979), our new formula shows almost the same extra-framework cation content, but it is significantly different for framework cation, anion and water molecule contents. In fact, apart from the presence of $\mathrm{Be}$ (absent in Galli's formula), the framework contains almost the same number of $\mathrm{Al}$ atoms (15 against 16 ), but it is decidedly Si-poorer (28 against 32 atoms). According to Galli (1980), the $32 \mathrm{Si}$ and $16 \mathrm{Al}$ atoms of his formula are distributed, in an ordered way, in three independent tetrahedral sites (multiplicity 16), coded $\mathrm{Si}(1), \mathrm{Si}(2)$, and $\mathrm{Al}$ respectively. Since the average interatomic distances, $\mathrm{Si}(1)-\mathrm{O}=1.62 \AA, \mathrm{Si}(2)-\mathrm{O}=1.63 \AA$, and $\mathrm{Al}-\mathrm{O}=1.715 \AA$, differ from the values of 1.603 and $1.761 \AA$ quoted by Jones (1968) for a tetrahedron centered by $\mathrm{Si}$ or $\mathrm{Al}$ respectively, Galli suggested some substitution of $\mathrm{Si}$ atoms by $\mathrm{Al}$, and vice versa, in the tetrahedral sites. By assuming the same chemical composition here obtained for the sample studied by Galli, the framework content may be distributed as follows: the two $\mathrm{Si}$ sites are fully occupied by $27.79 \mathrm{Si}$ and 4.21 $\mathrm{Al}$ atoms $(86.8 \%$ of $\mathrm{Si}$ and $13.2 \%$ of $\mathrm{Al})$, the Al site is fully occupied by $10.71 \mathrm{Al}$ and $5.29 \mathrm{Be}$ atoms $(66.9 \%$ of $\mathrm{Al}$ and $33.1 \%$ of $\mathrm{Be})$. The average interatomic distances calculated with such a distribution give values of $1.623 \AA$ for Si sites and $1.724 \AA$ for the Al site, very similar to those found by Galli (1980) in his structural refinement. By considering $\mathrm{Be}$, instead of $\mathrm{Al}$, in $\mathrm{Si}$ sites, the calculated average interatomic distances are 1.609 and $1.754 \AA$ for Si sites and $\mathrm{Al}$ site respectively, values quite different from those found by Galli. The presence of $\mathrm{Al}$ atoms in $\mathrm{Si}$ sites and of $\mathrm{Be}$ atoms in $\mathrm{Al}$ site is hence very likely in roggianite, and a close chemical similarity between roggianite from Alpe Rosso, here studied, and roggianite from Pizzo Marcio, used for structural refinement, is again strongly emphasized.

As far as the anionic content is concerned, the chemical formula obtained in this work is characterized, in agreement with structural data, by the presence of hydroxyl groups. The electrostatic charge balance, computed according to Donnay and Allman (1970), gives bond strength values very similar to those obtained by Galli (1980; Table 5). Nevertheless, our chemical formula differs significantly from that proposed by Galli (1980): the $\mathrm{OH}(1)$ site (multiplicity 16), assigned by Galli to hydroxyls, is occupied by 2 oxygens 


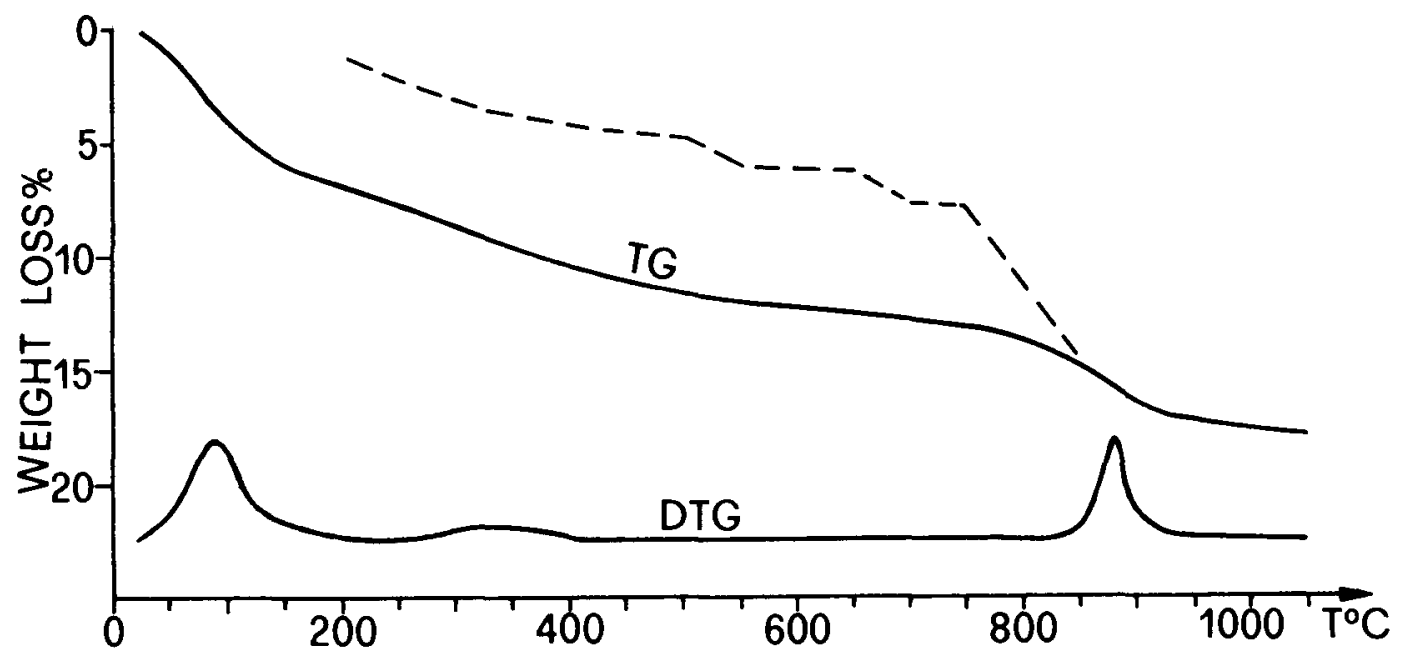

FIG. 1. TG, DTG and rehydration curves of roggianite.

and by 14 hydroxyls, while the $\mathrm{OH}(2)$ site (multiplicity $=16$ ), assigned by Galli to hydroxyls is occupied by $2(\mathrm{OH})$, the remaining by water molecules. Consequently, our formula shows a minor content of both framework and extraframework hydroxyls, and more water molecules. The amount of hydroxyl in our formula corresponds to a $\mathrm{H}_{2} \mathrm{O}$ loss of $3.47 \%$, a value very close to the weight loss $(3.60 \%)$ observed in TG analysis between $850^{\circ} \mathrm{C}$ and $1050^{\circ} \mathrm{C}$. In fact, the mineral does not regain the weight loss after heating to $850^{\circ} \mathrm{C}$ (see next section) and it was found to transform into a feldspar after heating at $900^{\circ} \mathrm{C}$ (see previous section).

\section{Zeolitic behaviour}

Since the reversible dehydration and the ion exchange capacity are considered peculiar and distinctive physical properties of the zeolitic minerals, roggianite, showing a zeolite-like structure, was tested for these properties.

Reversible dehydration. By using a Du Pont thermobalance, pure roggianite powder was heated to various temperatures and then cooled and maintained at room temperature for 12 hours. With a heating rate of $10^{\circ} \mathrm{C} / \mathrm{min}$, the powder was heated between $200^{\circ} \mathrm{C}$ and $900^{\circ} \mathrm{C}$ at intervals of $50^{\circ} \mathrm{C}$. The rehydration curve (Fig. 1) shows that roggianite regains most of the weight loss until heated to $750^{\circ} \mathrm{C}$. At temperature higher than $750^{\circ} \mathrm{C}$, the rehydration capacity of roggianite decreases and becomes very low at $800^{\circ} \mathrm{C}$ and zero at $850^{\circ} \mathrm{C}$. Since at about $850^{\circ} \mathrm{C}$ a faster weight loss begins (see TG and DTG curves in Fig. 1), this reaction very likely corresponds to the hydroxyl loss with the consequent framework breakdown.

Ion exchange capacity. $3.7 \mathrm{mg}$ of pure powdered material was placed in a glass tube containing $3 \mathrm{~cm}^{3}$ of a $\mathrm{Na} 1 \mathrm{~N}$-solution prepared with Merck 'suprapur' $\mathrm{NaCl}$ and deionized water. The tube was slowly oscillated in an oven at $60^{\circ} \mathrm{C}$ for 10 days. The solution, carefully filtered, was then tested for Ca content by atomic absortion spectrophotometer. It was found to contain $4.20 \mathrm{wt} . \%$ $\mathrm{CaO}$; as 19.20 is the weight percent of $\mathrm{CaO}$ in roggianite, this means that little more than $\frac{1}{5}$ of the $\mathrm{Ca}$ has been exchanged. This value is low when compared with that generally shown by most zeolites, but it may be explained taking into account the structural features of the mineral. In fact, the $\mathrm{Ca}$ atoms lie in the cavities where the tetrahedral framework is interrupted, and are firmly bound to the framework, as they are octahedrally coordinated by two oxygens and four hydroxyls. On the other hand, the doubling of the exchangeable cation number due to the $\mathrm{Na}$ $\rightarrow \mathrm{Ca}$ substitution, requires, besides complete occupancy of the $\mathrm{Ca}$ sites, accommodation of some $\mathrm{Na}$ cations in other sites (i.e. largest channels), probably less electrically favourable.

\section{Conclusion}

The check of reversible dehydration and cation exchange capacity, allows us to classify roggianite among the zeolitic minerals, as already suggested by Galli (1980) on the basis of its structural features. New chemical data revealed a substantial 
amount of $\mathrm{Be}$ and $(\mathrm{OH})$ groups. Therefore, roggianite is the first and up to now the only zeolite with many tetrahedral sites occupied by Be atoms; in particular, the structural data (Galli, 1980) suggest that $\mathrm{Be}$ atoms are present only in $\mathrm{Al}$ tetrahedra. Among the zeolitic minerals, the interrupted framework for the $(\mathrm{OH})$ groups is known in partheite (Engel and Yvon, 1984); unlike partheite, roggianite is characterized also by the presence of extra-framework $(\mathrm{OH})$ groups, which is unique in this group of minerals.

\section{Acknowledgements}

The authors thank $\mathrm{G}$. Gottardi for the critical reading of the manuscript and J. A. Mandarino for some useful suggestions. The Consiglio Nazionale delle Ricerche of Italy is also acknowledged for financing the electron microprobe laboratory at the Istituto di Mineralogia e Petrologia of the University of Modena; thanks are also due to the Centro Interdipartimentale di Calcolo Automatico e Informatica Applicata of the University of Modena. This work was made possible through the financial support of M.P.I. (Ministero della Pubblica Istruzione).

\section{Note}

After submission of the manuscript, Voloshin et al. (Mineral. Zh. 8, 85-90, 1986) published a paper on a new calcium-beryllium silicate named glnzburgite. Except for a lower water content, this mineral has che- mical formula and unit cell dimensions very close to those here reported for roggianite.

\section{References}

Albee, A. L. and Ray, L. (1970) Correction factors for electron-probe microanalysis of silicates, oxides, carbonates, phosphates and sulphates. Anal. Chem. 42, 1408-14.

Alberti, A. (1976) The use of structure factors in the refinement of unit-cell parameters from powder diffraction data. J. Appl. Crystallogr. 9, 373-4.

Donnay, G. and Allmann, R. (1970) How to recognize $\mathrm{O}^{2-}, \mathrm{OH}^{-}$, and $\mathrm{H}_{2} \mathrm{O}$ in crystal structures determined by X-rays. Am. Mineral. 55, 1003-15.

Engel, N. and Yvon, K. (1984) The crystal structure of partheite. Z. Kristallogr. 169, 165-75.

Galli, E. (1980) The crystal structure of roggianite, a zeolite-like silicate. Proc. 5th Int. Conf. Zeolites (Rees L.V.C., ed.) Heyden, London, 205-13.

Gard, J. A. (1969) An electron microscope and diffraction study of roggianite. Clay Mineral. 8, 112-3.

Gottardi, G. and Galli, E. (1985) Natural zeolites. Springer-Verlag. Berlin-Heidelberg.

Jones, J. B. (1968) Al-O and $\mathrm{Si}-\mathrm{O}$ tetrahedral distances in aluminosilicate framework structures. Acta Crystallogr. B24, 355-8.

Passaglia, E. (1969) Roggianite a new silicate mineral. Clay Mineral. 8, 107-11.

Vezzalini, G. and Mattioli, V. (1979) Secondo ritrovammento della roggianite. Period. Mineral. 48, 15-20.

Ziebold, T. O. and Ogilvie, R. E. (1964) An empirical method for electron microanalysis. Anal. Chem. 36, 322-7.

[Manuscript received 13 October 1986;

revised 27 May 1987] 